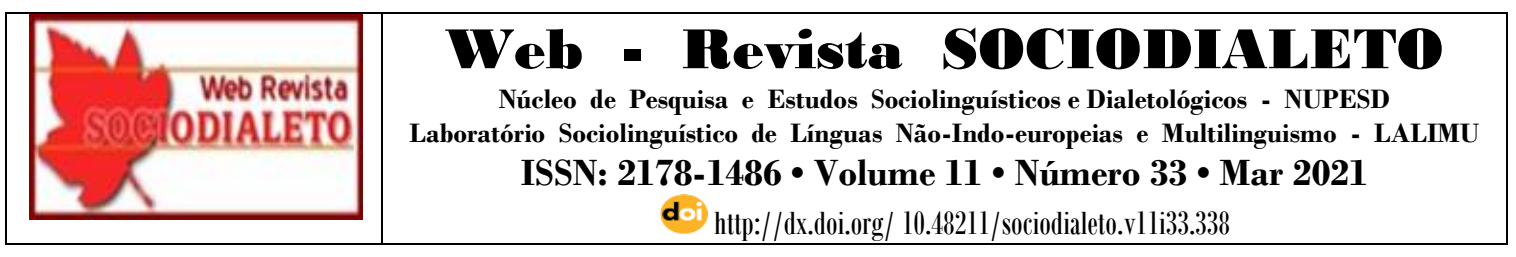

\title{
AS LÍNGUAS DA FRONTEIRA BRASIL-BOLÍVIA: CRENÇAS E ATITUDES LINGUÍSTICAS
}

THE LANGUAGES OF THE BRAZIL-BOLIVIA BORDER: LINGUISTIC BELIEFS AND ATTIUDES

\author{
Stael Moura da Paixão Ferreira (UFMS) ${ }^{1}$ \\ staelmoura@hotmail.com \\ Rosangela Villa da Silva (MEF-UFMS/PPGEL-UFMS) ${ }^{2}$ \\ rvilla45@hotmail.com
}

\begin{abstract}
RESUMO: Neste trabalho, apresentamos grandes considerações acerca do comportamento linguístico na fronteira Brasil - Bolívia, delimitada pelas cidades de Corumbá e Ladário (BR) e Arroyo Concepción, Puerto Quijarro/Puerto Suarez (BO). O objetivo é refletir a dinâmica dos contatos linguísticos das línguas portuguesa e espanhola nesta região de fronteira, considerando as peculiaridades do português e espanhol na modalidade falada e escrita, bem como a própria integração fronteiriça, por meio dos contatos de outras línguas também existentes, registrando a importância de refletir as hibridações étnicas, culturais e sociais, presentes na singularidade dos contatos dos próprios sujeitos fronteiriços. Registramos neste estudo, a mescla de culturas e de identidades que integram os dois países limítrofes, apresentando línguas minoritárias e fatores extralinguísticos, que influenciam nas atitudes linguísticas e na manifestação da heterogeneidade cultural na fronteira Brasil-Bolívia.
\end{abstract}

PALAVRAS-CHAVE: Sociolinguística, Línguas em contato, Atitudes linguísticas na fronteira Brasil-Bolívia

\begin{abstract}
In this work, we present great considerations about linguistic behavior on the Brazil Bolivia border, delimited by the cities of Corumbá and Ladário (BR) and Arroyo Concepción, Puerto Quijarro / Puerto Suarez (BO). The objective is to reflect the dynamics of the linguistic contacts of the Portuguese and Spanish languages in this border region, considering the peculiarities of Portuguese and Spanish in the spoken and written modality, as well as the border integration itself, through the contacts of other languages also existing, registering the importance of reflecting the ethnic, cultural and social hybridizations, present in the singularity of the contacts of the border subjects themselves. In this study, we recorded the mixture of cultures and identities that integrate the two bordering countries, presenting minority languages and extralinguistic factors, which influence linguistic attitudes and the manifestation of cultural heterogeneity on the Brazil-Bolivia border.
\end{abstract}

KEYWORDS: Sociolinguistics; Languages in contact; Linguistic attitudes on the Brazil-Bolivia border.

\footnotetext{
${ }^{1}$ Professora Pesquisadora UFMS-CPAN. Mestre em Estudos Fronteiriços - MEF/ UFMS/CPAN. Linha de Pesquisa: Ocupação e Identidade Fronteiriças e Linha de Pesquisa: Literatura e Ensino de LínguasUFMS/CPAN. Universidade Federal de Mato Grosso do Sul - UFMS - Corumbá - MS - Brasil.

2 Doutora em Linguística da Língua Portuguesa pela UNESP. Pós-Doutorado em Sociolinguística pela Universidade de Coimbra - Portugal. Professora Orientadora do Programa do Mestrado em Estudos Fronteiriços- MEF/UFMS/CPAN e do Mestrado em Estudos de Linguagens (CCHS) Universidade Federal de Mato Grosso do Sul - UFMS - Corumbá - MS - Brasil.
} 


\section{As Crenças e Atitudes Linguísticas na Fronteira Brasil- Bolívia}

Sabemos que o comportamento linguístico, do ponto de vista sociológico deve ser analisado por meio de fatores histórico, sociais, culturais e econômicos. Na sociolinguística, as crenças e atitudes linguísticas, provenientes da Psicologia Social de Lambert (1975), são responsáveis por identificar o comportamento linguístico a partir das relações de prestígio/status linguístico e desprestígio/ estereotipação estabelecidas entre os falantes de uma língua. No entanto, a proposta desse estudo foi de analisar a língua, em situações reais de uso, elencando conceitos indispensáveis para a compreensão do que acontece quando línguas diferentes entram em contato numa região de fronteira.

No entanto, alertamos sobre a necessidade e a importância de, nesta região de fronteira, refletir alguns aspectos, que podem ser compreendidos como indicadores da relação que se estabelece entre língua, falante e sociedade (LABOV, 1976), comparando brevemente com alguns preceitos teóricos, anteriormente apresentados por Meillet (1921), bem como por autores como Nicolai Marr (1865-1934), que sustenta uma abordagem social da língua, feita numa corrente marxista, que sugere a língua como instrumento de poder.

Por ser a língua um fato social, a linguística é uma ciência social, fruto da mudança social (MEILLET, 1921 apud CALVET, 2002, p. 16). Desta maneira, compreendemos que, para o linguista, a língua é variável e motivada estritamente por fatores sociais. Assim, Meillet (1921) busca explicar a estrutura linguística por meio de fatores históricos e sociais e, como vimos, esse pensamento foi retomado por Labov décadas depois. Então, destacamos que, a partir da herança de Meillet (1921), a noção de língua como fato social dinâmico, cuja variação é explicada pela mudança social, ou seja, por questões externas, ganha força, e posteriormente com a herança de Bakhtin, a perspectiva de que a língua é um fenômeno, cuja natureza é ideológica, renova-se.

Salientamos, aqui, que a linguística de Marr, mesmo com suas ideias confusas sobre a existência de "línguas de classe" e sua definição de língua como "superestrutura", e que foi posterior e severamente, classificada como nociva, conforme 
aponta Tchougounnikov (2005). No entanto, essa doutrina, chamada "marrismo", ajudanos a compreender que comunidades linguísticas, inclusive as que se apresentam em situações de fronteira, não podem ser vistas somente enquanto "gênese da linguagem" em função das atividades produtivas, nem tampouco podem estar apenas relacionadas com a "evolução da sociedade", como sugere o autor, mas os acontecimentos históricos, culturais e discursivos justificam seu comportamento.

Neste contexto, as crenças e atitudes linguísticas nesta fronteira Brasil - Bolívia, não podem ser compreendidas com neutralidade, pois as intencionalidades são ideologicamente apresentadas, conforme apresenta Bakhtin (1988), ou seja, estão em conformidade com as necessidades históricas humanas dos sujeitos, fenômeno social. Assim, o conceito de língua nesta zona de fronteira, também pode ser visto como um fato social, conforme salienta linguístico Whitney (2010), que embora não tenha usado essa expressão, e sim, a terminologia “instituição social”, também já imprimia na língua características próprias dos fatos sociais.

Segundo MARRA, Daniel \& MILANI, Sebastião Elias (2013):

Evidencia-se, finalmente, que, na concepção de Whitney, os indivíduos podem criar novas formas linguísticas e modificar as já existentes. Porém, é no seio da comunidade que essas formas serão moldadas e receberão os contornos característicos de seus falantes. Mas o fato a ser observado é que, para Whitney, são os indivíduos que mudam a língua e as ações que a forçam à mudança obedecem a um único princípio: o de estar constantemente se adaptando às circunstâncias e às necessidades de seus usuários. (MARRA, Daniel \& MILANI, Sebastião Elias. 2013. p.130)

Consequentemente, a língua nesta fronteira é uma variável situacional, considerando ainda que as atitudes aqui apresentadas também influenciam comportamentos e são importantes para explicar o funcionamento das línguas em contato. Além disso, são averiguadas em situações, seja para fins comerciais, seja na aplicação de situações como povos oriundos de outros países que vivem e aprendem uma nova língua, ou seja em aplicação de relações de simples convivência. 
No entanto, esclarecemos que em relação a esta zona fronteiriça, especificamente a localizada entre os municípios de Corumbá/MS (Brasil) e Puerto Suárez, na Bolívia, os estudos sobre crenças e atitudes linguísticas, exceto para grupos ainda muito restritos, carecem de pesquisas que busquem explicar profundamente o desempenho desses elementos, considerando que percebemos que os estudos ainda são pequenos, tímidos e insuficientes. Mas sabemos que as pesquisas já existentes podem auxiliar na identificação dos fatores que atuam sobre as mudanças, comportamentos e alternâncias das línguas aqui presentes, bem como dos aspectos que são considerados fatores decisivos na formação da consciência linguística e na explicação da competência dos falantes. Por meio da identificação das crenças e atitudes linguísticas, nesta fronteira, podemos conhecer as reações subjetivas diante do contato linguístico dos falantes e sua influência na aquisição de segundas línguas, como sugere Gómez Molina (1998).

Pretende-se, neste capítulo, apontar, a partir da descrição e análise dos dados encontrados, fatores que revelam o posicionamento do falante da fronteira BrasilBolívia, diante das diferentes línguas e culturas presentes nesta localidade, identificando suas crenças e atitudes nas duas comunidades linguísticas. Ressaltamos que a coleta dos dados se deu por meio do método da observação direta e do uso de diálogos informais, com perguntas despadronizadas, através de conversação espontânea. Afirmamos, então, que a diversidade linguística aqui encontrada é oriunda do contato entre culturas, línguas, etnias, identidades e falares diversos, determinada pela valorização e pelo prestígio da linguagem na localidade, dado o dinamismo que as línguas apresentam por ser uma região de fronteira. Na mesma visão, acrescentamos que é um novo olhar, um olhar interdisciplinar sobre a pesquisa linguística, em que se estuda a maneira como a linguagem se relaciona com a sociedade e sua cultura nesta zona de contato fronteiriço.

Levantamos, para isso, informações sobre a formação histórica da região, considerando que não seria possível desvincular a dimensão histórico-social do estudo da linguagem, pois, é importantíssimo considerar as pressões sociais exercidas, sob a forma de força social presentemente ativa sobre a língua, conforme Labov (1976). 
Assim, salientamos que as atitudes e as crenças linguísticas são aqui estudadas e apoiadas na sociolinguística, por meio das conexões presentes em diferentes situações sociais, investigando, assim, os fronteiriços inseridos no seu contexto in loco, ou seja, em situações reais de uso da língua. Para isso, retomamos também a concepção de Lambert (1967), Lambert e Lambert (1975) e Cargile et al. (1994) que apontam que a atitude linguística é, ao mesmo tempo, o saber ou crença (componente cognitivo ou cognoscitivo); a valoração (componente afetivo); e a conduta (componente conativo), ou seja, de natureza comportamental, o que significa dizer que a atitude linguística de um indivíduo nesta fronteira é o resultado da soma de suas crenças, conhecimentos, afetos e tendências a comportamentos diante de sua língua ou de uma situação sociolinguística. Assim, sobre esses fatores, tentamos registrar o papel que cada um desses componentes representa na manifestação da atitude linguística do falante nesta zona de fronteira. Mas, salientamos que as análises feitas sobre os falantes naturais fronteiriços deram-se frente ao que consideramos extremamente profícuos e importantes.

Desta maneira, comungando do pensamento de Gómez Molina (1998), consideramos que o componente cognoscitivo, ou seja, a crença, nesta fronteira, teria o maior peso sobre os demais, por conformar a consciência sociolinguística, uma vez que intervêm os conhecimentos e pré-julgamentos dos fronteiriços. Segundo Gómez Molina (1998), a atitude linguística constitui-se em consciência linguística, crenças, estereótipos, expectativas sociais (prestígio, ascensão), grau de bilinguismo, características da personalidade, etc.

Por outro lado, o componente afetivo estaria alicerçado em juízos de valor, ou seja, estima e ódio, acerca das características da língua, além da associação com traços de identidade, etnicidade, valor simbólico, orgulho e sentimento de solidariedade com o grupo a que pertence, como aponta Gómez Molina (1998). Já o componente conativo, ou seja, a conduta, que refletiria a intenção, o plano de ação, em determinados contextos e circunstâncias, mostrando, assim, a tendência a atuar e a reagir em diferentes domínios ou âmbitos sociais (rua, casa, escola, loja, trabalho) (GÓMEZ MOLINA, 1998). 
Para essa análise, diferenciamos, a saber, primeiramente, fatores relacionados à existência das línguas portuguesa e espanhola e, posteriormente, as demais línguas presentes em ambos os países, e a manutenção dos elementos característicos, tanto na fala dos bolivianos como na dos brasileiros, levando-se em conta a caracterização de situações bilíngues, como por exemplo, o status dos falantes e das línguas, os papéis e as funções sociais, o domínio linguístico e social, assim como as condições linguísticas, formais ou informais, e culturais em que esse bilinguismo é desenvolvido.

Para tentar facilitar a compreensão, buscaremos elucidar, mais claramente, a situação, separadamente, presente em ambos os lados da fronteira. Iniciaremos com uma breve reflexão no lado boliviano, considerando as questões históricas, sociais e culturais tanto dos portenhos, nascidos em Puerto Suárez, como dos moradores oriundos de outras regiões. Analisaremos também as relações cotidianas, e o contato linguístico dos que vivem nessa fronteira. Por fim, registraremos, por meio de observação naturalista, ou seja, sem interferência, a interessante e singular situação linguística no lado brasileiro composta de falantes de várias nacionalidades.

No entanto, destacamos ainda que esse estudo se faz presente num espaço intercultural, na fronteira entre língua e sociedade. Desta forma, focalizamos os empregos linguísticos concretos, todos legítimos, em que se consideram, em especial, os de caráter plenamente heterogêneo, já que a fronteira analisada é plenamente heterogênea. Além disso, analisar as atitudes linguísticas nesta fronteira consiste em efetuar avaliações subjetivas sobre o valor das variedades linguísticas e sobre seus falantes, considerando que para Lambert e Lambert (1975) atitude é:

Uma maneira organizada e coerente de pensar, sentir e reagir em relação a pessoas, grupos, questões sociais ou, mais genericamente, a qualquer acontecimento ocorrido em nosso meio circundante. Seus componentes essenciais são os pensamentos e as crenças, os sentimentos (ou emoções) e as tendências para reagir (LAMBERT E LAMBERT (1975, p.100).

Desse modo, os dados coletados na pesquisa para construção desta análise mostraram-se satisfatórios tanto sobre as crenças e atitudes linguísticas na região, quanto às menções as variações e contatos linguísticos nesta fronteira Brasil-Bolívia. 


\section{Análise Parcial de Algumas Atitudes Linguísticas no Lado Boliviano}

Como sabemos, Puerto Suárez é a sede da Primeira Seção Municipal, composta ainda por Puerto Quijarro e El Carmen Rivero Torrez, e é capital da Província de Germán Bush, pertencente ao departamento de Santa Cruz, sendo considerado um dos povoados fronteiriços mais antigos do Departamento de Santa Cruz, criado em 10 de novembro de 1876 e localizado às margens da baía Cáceres, à margem direita do Rio Paraguai. Em 1919, Puerto Suárez foi ligado a Santa Cruz, por estrada e via férrea de $651 \mathrm{~km}$, o que atraiu migrantes de outros departamentos bolivianos (SEBRAE/MS, 2010).

Com base nos dados coletados na pesquisa, a população da Província de Germán Bush é de origem chiquitana, sendo atualmente formada por mestiços oriundos do oriente boliviano e por imigrantes andinos e brasileiros. Sobre isso, abordaremos mais adiante, no entanto, faz-se necessário ressaltar que, em um contexto histórico, póscolonialismo, a formação do Estado boliviano moderno também seguiu o mesmo modelo de formação europeu, e desta maneira, houve a legitimação de algumas nações, pelo governo, e a marginalização de outras, pelo seu não reconhecimento, conforme aponta Seiffert e Almeida (2014). Como na Bolívia reconhecem-se 36 nações originárias, além do idioma oficial, o espanhol, na constituição, exceto as línguas de nações ainda não reconhecidas.

Segundo os autores Seiffert e Almeida (2014), o reconhecimento do plurinacionalismo constitucional, deu-se pelo fato de que as nações indígenas sofreram um verdadeiro genocídio por seus colonizadores, tornando a construção de uma constituição plurinacional uma medida necessária. Então, foi nesse cenário de recompensação que surge a verdadeira participação dos demais povos nativos desse território nesse Estado, como sugerem Seiffert e Almeida (2014). Além disso, sabemos que a Bolívia jamais teve indígena como mandatários em períodos anteriores a este, embora sua população, desde a criação do país, em 1825, seja majoritariamente formada por aqueles que se autodenominam na atualidade como "pueblos originários".

Desta maneira, podemos compreender que: 
Séculos de exclusão a que sociedades e culturas indígenas foram submetidas contribuíram para a construção do arquétipo nacional boliviano. Assim, muitos conhecimentos foram perdidos, nações inteiras exterminadas. É possível crer que um discurso identitário e alusões culturais à soberania territorial poderiam ser vistos como garantia ao acesso a níveis mínimos de cidadania (CÂMARA, 2005A).

Sem questionar o critério de auto identificação dos grupos bolivianos utilizado pelo Censo 2001, afirmamos que, como supracitado, convivem, neste território, inúmeros e diferentes grupos étnicos indígenas, dentre os quais podemos destacar os Aymará, os Quéchua e os Guarani e o expressivo contingente de "minorias étnicas": os Chiquitano, os Chiriguano e os Ayoreo, além, é claro, de um complexo emaranhado de categorias sociais como "mestizos" e "cholos", conforme dados levantados pela ONU(2005).

Esses breves esclarecimentos ajuda-nos a compreender a sociedade boliviana in loco, e suas atitudes linguísticas residem exatamente na compreensão de que se por aqui não se pode pensar em monoetnicidade, tampouco monoculturalidade (CÂMARA, 2005B), também não se pode cogitar a possibilidade da existência de uma língua una. Considerando que a atual constituição boliviana reconhece o país como multiétnico e pluricultural, deve-se, então, crer na existência de multietnicidades e multiculturalidades, mas, em especial, crer num antagonismo que vai além de ocidente e oriente, equivalente à oposição entre bolivianos oriundos das regiões altas (andinas, altiplânicas) e baixas, mas num cenário multifacetado por conta da existência da resistência de uma elite dominante em perceber-se e manter-se como tal e de uma oposição marginalizada, consagrada como "minoria étnica" em oficializar-se.

Percebemos, então, que para se compreender o atual cenário linguístico boliviano é necessário, pois, montar um verdadeiro mosaico de grupos que compõem sua rica diversidade étnica e pluricultural, tratada por muito tempo como motivo de "atraso" e "subdesenvolvimento" da Bolívia. Assim, por compreender que a característica central de pertencimento e ligação a uma determinada cultura é a 
linguagem, enquanto código de transmissão, atitudes, elemento significativamente subjetivo, mas representante da memória social e do conjunto de determinantes simbólicos, convém destacar que no lado boliviano, as culturas são preservadas, processadas e transmitidas através das diversas linguagens, que estrategicamente mantem, desenvolvem e transmitem cultura, enquanto garantia de sobrevivência do grupo social identitário.

Quando apontamos as atitudes linguísticas dos falantes no lado boliviano da fronteira, voltamo-nos tanto para atitudes cognitivas, porque sobre elas implicam crenças sobre o mundo; como para as afetivas, porque possuem sentimentos sobre a própria língua; e de natureza comportamental, porque estimula certas ações e transformações. Assim, sustenta-se que a atitude linguística vista aqui, na fronteira, é como um processo, dotado de certas etapas, e não simplesmente como um todo ou como um resultado, como aponta Alves (1979). A tendência a certo tipo de ação torna esse o resultado, produto final desse confronto identitário. Ou seja, a percepção linguística, deve-se ao fato da estreita relação de demonstração e enquadramento no sistema de crenças e valores do indivíduo boliviano e sua eventual reação emotiva com o próprio sistema.

Com base nesse pensamento, percebe-se que apesar das profundas mudanças e alterações na dinâmica das línguas indígenas, devido à "castellanización” forçada, não tanto pelo sistema educacional, mas pelos meios de comunicação, alguns bolivianos, jovens, nascidos nesta fronteira, têm como sua primeira língua só o castelhano, embora sejam considerados indígenas. Estes atravessam a fronteira para estudar em universidade brasileira, na cidade de Corumbá, e utilizam, enquanto em contato com brasileiros, a língua portuguesa como meio de comunicação. Ao retornarem para Puerto Suárez (BO), retomam o idioma castelhano, considerando que a língua dominante é tida como língua de prestígio que substitui as línguas nativas.

Percebemos, em nossas análises, que pesam poderosamente sobre a região os fatores associados a "discriminación y marginamiento" em que se encontram boa parte da população indígena, mas estes serão posteriormente abordados. Salientamos apenas que, segundo Censo 2001, o principal motivo da criação de estereótipos sociais é que a 
própria população indígena boliviana se manifesta sob uma "subdeclaración" de “discriminación, racismo y exclusión". Por outro lado, nesta declaração, alguns indígenas bolivianos afirmam que, tanto em relação ao idioma falado, como em relação à própria autodefinição, é essa uma maneira de se tornarem "invisibles" evitando “etiquetas y estigmatización social” (Censo 2001). Assim, para termos uma compreensão das atitudes linguísticas, é importante incorporar o estudo de crenças e valores, porque ambos os termos estão inter-relacionados à construção do próprio sistema linguístico.

Além disso, ressaltamos, no entanto, que paralelamente, ao espanhol, a população concentrada em Puerto Suárez, incluindo os portenhos e quijarrenhos, como são chamados os nascidos respectivamente em Puerto Suárez e Puerto Quijarro, empregam as línguas indígenas na vida cotidiana, como quéchua e aymará, o que abre para nós, pesquisadores, novas possibilidades de pesquisas, posteriormente mais aprofundadas, sobre esses processos de transformação linguística, principalmente os relacionados à expansão do idioma dominante e diminuição e/ou desaparecimento de alguns idiomas indígenas, e de expansão de alguma das línguas indígenas em detrimento de outras, como, por exemplo, o idioma chiquitano está se perdendo lentamente na região (SEBRAE/MS, 2010).

Segundo aponta o SEBRAE/MS (2010):

No município de Puerto Suárez, 6,14\% da população fala somente um idioma nativo, enquanto $83 \%$ das pessoas com mais de 6 anos fala somente espanhol e $16 \%$ falam dois idiomas (espanhol e um idioma nativo). Dentre a população do município que tem como idioma materno uma língua nativa, $40 \%$ falam quéchua e $39 \%$ guarani. (SEBRAE/MS, 2010, p. 189)

Ainda conforme aponta o SEBRAE/MS (2010):

No município de Puerto Suárez, 4,3\% da população é analfabeta e a média de anos de estudo da população com mais de 19 anos é de 8,05 anos, concentrados na população de idioma não nativo e semelhante entre homens e mulheres. As taxas de abandono da escola são de $4,1 \%$ no ensino primário e de $2,8 \%$ no nível secundário, sendo que $96,3 \%$ 
da população em idade escolar frequentam a escola. (SEBRAE/MS, 2010, p. 189)

Depois de Puerto Suárez, Puerto Quijarro é o segundo município mais importante. Historicamente é um dos poucos portos fluviais soberanos da Bolívia, onde se encontra uma Zona Franca. Em Puerto Quijarro, as comunidades indígenas estão instaladas em 98.000 hectares de área preservada. São em torno de 180 famílias Ayoreas distribuídas nas várias comunidades. A região apresenta várias fazendas de grande porte e dois assentamentos: Carmen de La Frontera e San Pedrito, segundo SEBRAE/MS (2010, p. 189).

Puerto Quijarro, segundo o SEBRAE/MS (2010), apresenta-se como um povoado mais moderno que outras localidades da região. A maior parte da sua população é constituída de migrantes. O grupo étnico do município é de origem chiquitana, cultura que está perdendo seus valores socioculturais. A população fala espanhol, quéchua, chiquitano e português. No entanto, o processo de aculturação está provocando a extinção do idioma chiquitano na região.

A língua espanhola é falada por $87,3 \%$ dos homens e $84,5 \%$ das mulheres. O quéchua é falado por 18,2\% dos homens e 17,3\% das mulheres e o aymará é falado por $16,1 \%$ dos homens e $15,2 \%$ das mulheres. Dentre a população do município que tem como idioma materno uma língua nativa, 64\% falam quéchua, 31\% aymará e 6\% guarani, de acordo com o SEBRAE/MS (2010).

Segundo o professor Cerrón (1987):

O aimará provém do Chavín (surgido faz 3.000 anos em Ancash, norte/centro peruano) e o quéchua do Huari (em Ayacucho, centro-sul peruano, faz 1,500 a 1,100 anos). Os primeiros incas vieram da Bolívia e foram abandonando sua puquina original para adotar a língua de Cuzco (que então era o aimará) e depois a do Chinchaysuyo (toda a zona ao norte de Cuzco) que é a quéchua e que se originou da maior língua do império. A história dá estranhas voltas. O termo camba já não é usado como um adjetivo relativo às tribos amazônicas, mas com orgulho, por um nacionalismo branco e anti-indigenista. A palavra colla é empregada para especificar os povos cujas línguas quéchua e aimará lhes foram impostas a partir do atual Peru. (CERRÓN-PALOMINO, R., 1987) 
No entanto, destacamos que, em Arroyo Concepción, fronteira que liga Puerto Suárez e Puerto Quijarro com a cidade de Corumbá (BR), estabelece-se o contato linguístico nas relações decompra e venda no comércio da cidade boliviana, considerando que o comerciante boliviano, que consegue entender a exigência do cliente brasileiro, consegue ter vantagem na comercialização de seus produtos. Desta forma, estamos pensando em uma região que é bilíngue, em relação ao espanhol e línguas indígenas, e ao mesmo tempo empregam a língua portuguesa em contatos linguísticos variados. Podemos refletir, então, que, nesta região onde as relações comerciais são latentes, há contextos favoráveis a um possível trilinguismo, considerando que os nativos falam as línguas indígenas, o espanhol e ainda o português.

Considere-se outra situação singular que faz parte deste espaço fronteiriço, é o caso dos filhos de bolivianos com brasileiras, residentes no lado boliviano dessa fronteira. Essas crianças têm maiores chances de se tornarem falantes nativos nas duas línguas, ou até nas três línguas, por serem expostas, constantemente, desde cedo, em casa, a um de seus pais, ora falando espanhol, ora falando com seus familiares bolivianos o aimará, e o outro falando português. Para estes casos poderíamos dizer que esses sujeitos podem se tornar simultaneamente trilíngues.

Convém ressaltar que ao que tange ao registro histórico dessa região, podemos considerar que ainda está em formação. Todavia, destacamos aqui que, segundo Ota e Linhares (2004), nas transmissões das emissoras de rádios e de televisão de fronteira, verifica-se a existência de emissoras de rádio bilíngues e trilíngues, que apresentam uma programação variada, com informações direcionadas aos interesses das comunidades, principalmente, transmissão de recados. Essas transmissões são feitas em guarani, espanhol e português. Porém em relação a Corumbá, lado brasileiro, diferentemente, as emissoras de rádio e televisão, procuram manter sua transmissão na língua portuguesa com foco na produção local de notícias.

\section{Análise Parcial de Algumas Atitudes Linguísticas no Lado Brasileiro: Contatos Com a Língua Indígena.}


Faz-se necessário esclarecer que o estudo sobre as atitudes linguísticas nesta região está em andamento, mas ainda em fase embrionária. Assim, os dados aqui apresentados estão baseados tanto na bibliografia disponível nos arquivos do Instituto Luiz de Albuquerque, na cidade de Corumbá, bem como nos levantamentos efetuados durante a pesquisa. Desta forma, optamos por uma redação holística, sem centralização de detalhes minuciosos, mas levando em consideração que os resultados gerais poderão ser expostos posteriormente, quando a pesquisa for plenamente concluída.

Podemos afirmar seguramente que para se compreender as atitudes linguísticas neste lado brasileiro, faz-se necessário refletir bem a sua formação histórico-social. Antes de prosseguir é preciso explanar historicamente a respeito dessa questão. Começaremos, então, observar que os idiomas indígenas, assim como identidade e cultura específicas, foram gravados na toponímia do estado. Através de seu trabalho como guias de militares, aventureiros e geógrafos, os índios sul-mato-grossenses deixaram na população local marcas identitárias singulares.

Em se tratando dos idiomas indígenas, Mato Grosso do Sul abriga sete idiomas indígenas de cinco famílias diferentes, sendo considerada a região brasileira com maior diversidade linguística fora da Amazônia, conforme mostra o quadro abaixo:

\section{IDIOMA}

KAIOVÁ

NHANDEVA

KADIWÉU

TERENA

KINIKINÁU

GUATÓ

OFAIÉ

\section{FAMÍLIA LINGUÍSTICA}

Tupi-guarani

Tupi-guarani

Guaicuru

Aruak

Aruak

Guató

Ofayé

(REVISTA TEKOHÁ, 2012, p. 23).

Dentre os idiomas supracitados, o guató, é o idioma mais conhecido pela população, considerando-se que é falado pelos índios guató, filhos legítimos do Pantanal, índios canoeiros por excelência, que foram considerados extintos na década de 60, até por Darcy Ribeiro em sua célebre obra O Povo Brasileiro, mas foram 
redescobertos vivendo na periferia de Corumbá (MANGOLIM, 1993, p.114). Hoje, os guató ocupam uma ilha no meio do Pantanal, conforme aponta a Revista Tekohá (2012). Com a extinção das tribos guaxarapós e paiaguás, os índios guató ficaram conhecidos, historicamente, como últimos índios canoeiros do Pantanal. (REVISTA TEKOHÁ, 2012).

Ressaltamos também que a língua guató, que atualmente é falada apenas por quatro integrantes vivos, faz parte do tronco linguístico macro-jê, conforme a tabela a seguir:

$\begin{array}{lcccc} & & \text { Macro-Jê } & \text { Tronco } \\ \text { Bororo } & \text { Guató } & \text { Jê } & \text { Ofayé } & \text { Língua } \\ \text { Bororo } & \text { Guató } & \text { Kaingang } & \text { Ofaié } & \text { Família } \\ \text { Umutina } & & \text { Kayapó } & \\ & & \text { Xavante } & \\ & \text { Panará } & & \end{array}$

(REVISTA TEKOHÁ, 2012, p. 23).

No entanto, se há quase 30 anos a etnia guató passou da extinção ao reconhecimento, o mesmo não aconteceu com o seu idioma (REVISTA TEKOHÁ, 2012). Atualmente, uma das poucas na aldeia que ainda fala fluentemente o idioma tradicional, sofre com a ameaça de ser considerada uma língua extinta pela Unesco, considerando que os que ainda falam a verdadeira língua do guató estão idosos.

Com um grupo de apenas cinco falantes, atualmente, estabelecidos em uma área demarcada na região do Pantanal do Nabileque, na Aldeia Uberaba, também conhecida como ilha Ínsua ou Bela Vista do Norte, a língua classificada como ameaçada de extinção perde gradativamente seus falantes, como ocorrido na manhã de dois de abril de 2012, que mais um integrante, a índia Júlia Caetano, uma das indígenas mais idosas do Brasil, que vivia na companhia do filho Vicente, faleceu aos 111 anos. Dona Julia, Vicente e Veridiano eram os três guató mais idosos do grupo que habitavam a região.

Como hierarquicamente, a família guató é patriarcal, hoje, a liderança da aldeia é concentrada no Cacique Severo e sua esposa, Dalva. Severo Ferreira, é filho mais velho 
de dona Josefina, irmã de Dona Francolina Rondon, mais conhecida Dona Negrinha, tem aproximadamente entre 90 e 96 anos e é a única pessoa no mundo, a saber, o canto dos guató, música que na tribo acompanha danças e rituais, além de ser um chamado para guerra.

Destacamos ainda que apesar de ter crescido entre os índios e de falar a língua, Dona Negrinha não é guató puro, foi criada na aldeia com a mãe e a avó, ambas índias, no entanto seu pai era negro, conforme registrado no Documentário - Índios Canoeiros do Pantanal (RIBEIRO, 2015).

Em relação às línguas indígenas, estima-se que:

No século XVI existissem no Brasil cerca de 1.200 idiomas indígenas, mas apenas 181 sobreviveram até hoje e um quarto deles deve desaparecer até 2050, fazendo do Brasil o país com o maior número de idiomas classificados como em risco crítico de extinção (usados apenas por avós e idosos). Três línguas nesse estágio são exclusivas do Mato Grosso do Sul: guató, com quatro falantes; kinikináu, com onze falantes; e ofaié, com doze falantes. (REVISTA TEKOHÁ, 2012, p.23).

No que se refere à situação linguística, sabemos que os guató são monolíngues em português e após algumas iniciativas, da Secretaria de Educação e da FUNAI, estão utilizando saudações e algumas palavras em guató (POSTIGO, 2011). Sobre estudos da língua guató, encontramos os trabalhos do etnólogo Max Schmidt, destacando o trabalho Estudos de Etnologia Brasileira: peripécias de uma viagem entre 1900 e 1901. Seus resultados etnológicos, (SCHMIDT, 1942), que é uma tradução da obra Indianerstudien in Zentralbrasilien: Erlebnisse und ethnologische Ergebnisse einer Reise in den Jahren. 1900 bis 1901. (SCHMIDT, 1905), como aponta Postigo (2011). No entanto, não pretendemos nos aprofundar nas questões fonológicas, ressaltamos o tema indígena para trazer à tona os fatores culturais e identitários pertencentes aos fronteiriços.

Todavia, salientamos que atualmente, na Aldeia Uberaba, que fica na divisa de Mato Grosso com Mato Grosso do Sul, a 340 km de Corumbá pelo rio Paraguai, há uma escola ribeirinha, a Escola Estadual Indígena João Quirino de Carvalho "Toghopanãa" 


\begin{tabular}{|c|c|}
\hline $\begin{array}{r}\text { Web Revista } \\
\text { ODIALETO }\end{array}$ & $\begin{array}{l}\text { Núcleo de Pesquisa e Estudos Sociolinguísticos e Dialetológicos - NUPESD } \\
\text { Laboratório Sociolinguístico de Línguas Não-Indo-europeias e Multilinguismo - LALIMU } \\
\text { ISSN: } 2178-1486 \bullet \text { Volume } 11 \bullet \text { Número } 33 \bullet \text { Mar } 2021 \\
\text { doi } \text { http://dx.doi.org/ } 10.48211 \text { /sociodialeto.vlli33.338 }\end{array}$ \\
\hline
\end{tabular}

que atende a jovens e adultos indígenas Guató que desejam prosseguir os estudos em sua própria terra e, para tanto, solicitaram a instalação do Projeto Saberes da Terra na escola da aldeia à Secretaria de Estado de Educação de Mato Grosso do Sul (SED/MS), que se trata de um Curso de Educação de Jovens e Adultos (EJA) relacionado ao segundo segmento do Ensino Fundamental ( $5^{\mathrm{a}}$ a $8^{\mathrm{a}}$ séries) e financiado com recursos federais. $O$ fato interessante a ser analisado refere-se a que a língua utilizada nessa comunidade escolar (L1) é a Língua Portuguesa (SILVA, 2007).

Destacamos ainda que a totalidade dos jovens e adultos Guató, moradores da Ilha Ínsua, domina parcialmente a leitura e a escrita em língua portuguesa, realidade que é, em grande parte, fruto do trabalho realizado pelo único educador Guató habilitado em Curso Normal em Nível Médio (Magistério), ex-coordenador pedagógico na Escola (SILVA, 2007).

Figura 01. Distribuição de cartilhas aos alunos indígenas guató e material pedagógico de apoio à atuação do professor.

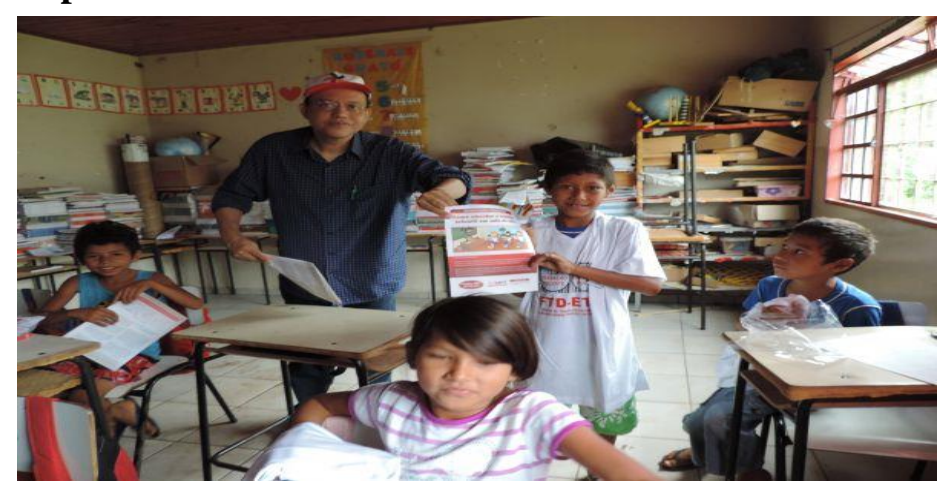

Fonte: AJALA, 2014.

Este professor por sua vez, desenvolve um trabalho com a língua indígena junto às séries iniciais, por meio de depoimentos, falas e cantos gravados e transcritos e a partir dos registros orais dos mais velhos. Desta forma, a recuperação desta língua indígena se dá de forma tímida.

Compreendemos que é natural a modificação, diversificação e transformação de uma língua, porque como expressão e veículo da cultura de um povo, ela é dinâmica. Mas, a morte de uma língua, é uma perda inestimável, considerando que se perde com 
ela um pouco da história, da cultura, e principalmente, um pouco da autoestima coletiva dos sujeitos.

Nessa perspectiva, observamos que os reais motivos para engajamento em atitudes linguísticas nesta fronteira somente poderão ser entendidos se considerarmos as práticas sociais, a interação entre indivíduos, ambientes e artefatos culturais. Assim, destacamos ainda que quando os índios guató, desde meados de 1950, por fatores políticos, econômicos, religiosos, forças da natureza, por motivos pessoais e de guerra, espalharam-se pantanal afora, inclusive fixando residências nas cidades que estavam no seu entorno, principalmente em Cáceres e Corumbá, ajuda-nos a compreender uma intensa carga invisível chamada "troca" de cultura presente nesta região. Não há uma estimativa de quantos indígenas residam fora da aldeia atualmente, no entanto alguns indígenas guató, os homens da aldeia, à procura de serviço, aceitam as mais diversas tarefas, tanto no Brasil como na Bolívia, em troca de seu esforço, trabalham catando isca para as lanchas de turismo, como peão de fazenda. Além de vários casos de alistamento militar, no qual os indígenas vão para a cidade e acabam se encantando com as "maravilhas" do centro urbano, e ao final do alistamento não voltam para a aldeia. Com as mulheres guató também encontramos este movimento, pois, muitas acabam se casando com não-índio e vão morar em Corumbá/MS.

Os casamentos dos indígenas com não-índios são um fator importantíssimo na "perda" da língua guató, considerando que se um dos pais não fala a língua indígena e ambos moram fora da aldeia, a língua portuguesa passa a ser predominante sobre a língua tradicional indígena, considerando a grande ampliação nas relações sociais que o indígena passa a manter usando a língua portuguesa. Além disso, outro fator que deve ser levado em consideração é o dos descendentes desses casamentos. Com a mãe ou o pai sendo não-índio, ganha-se parentes também não-índios (tios, avós e primos) e, frequentemente, padrinhos (e compadres) não-índios. No entanto, isso não significa que o indígena esteja interessado em abandonar sua identidade indígena. Mas, por outro lado, significa que, nessa situação, a língua não é vista como o mais importante da identidade étnica, mas sim a cultura, considerando que as tradições desses indígenas são 
mantidas, como por exemplo, encontramos nessas famílias a tradicional utilização da viola de cocho, para animar as reuniões familiares, chamadas de cururu.

Mais uma vez destacamos que todas essas informações são necessárias para que se compreenda a real situação linguística e cultural nesta fronteira. Sabendo que é há uma forte interdependência entre língua, cultura e identidade, refletir sobre "o complexo de valores, costumes, crenças e práticas que constituem o modo de vida de um grupo específico" (EAGLETON, 2005, p. 55), ou seja, as questões sociais presentes nesta fronteira brasileira ajudar-nos-á a refletir a intrínseca ligação entre cultura e língua e consequentemente os processos de identificação do sujeito fronteiriço e de suas ações diante do outro. Assim, as relações sociais na zona fronteiriça estreitam-se e as culturas, ideologias e conhecimentos são difundidos.

Essa tríplice aliança que acompanha o fronteiriço, enquanto ser social que é, é base que sustenta a vida social dos sujeitos, pois se faz presente nos diversos âmbitos que a circundam: social, religioso, familiar, político, educacional, ideológico, midiático, econômico, enfim, todas as relações sociais. Conforme Eagleton (2005, p. 55), a cultura possibilita ao indivíduo inserir-se e interagir, permite negociar "maneiras apropriadas de agir em contextos específicos". Nessa perspectiva, os sujeitos sociais fronteiriços são inseridos na comunicação verbal em um contínuo processo de construção. Além disso, por meio da língua, são inseridos na teia social, que possibilita o contato com a cultura, com as ideologias, com as identidades dos outros grupos sejam maioritários ou minoritários, tornando-se um instrumento para reforçar, suprir ou suprimir a própria cultura.

\section{Análise Parcial de Outras Atitudes Linguísticas no Lado Brasileiro: Contatos com as Demais Línguas Presentes em Corumbá-MS}

Podemos pensar, então, que o lado brasileiro da fronteira é monolíngue, e que aqui só se fala o português brasileiro e suas variações. Todavia, pensar assim é ignorar e exclui a outras diversidades, cultural e linguística, existentes neste lado da fronteira. É desconhecer as inúmeras línguas faladas pelos diversos grupos considerados "minoritários", pouco numerosos, mas não de baixo poder político, como os estrangeiros, falantes de sua língua tradicional, além da língua oficial do país. Desta 
forma, se somos uma região plural, com nível de interação linguística distinta, diversificada, logicamente também somos plurilíngues, considerando que coexiste uma variedade de línguas que compõem um mosaico no cenário linguístico neste lado da fronteira do Brasil.

Os falares dos fronteiriços, de diferentes línguas, estão refletidos no dia a dia, em nossa cultura, o que nos torna ainda mais singulares, únicos, diferentes de todas as outras áreas fronteiriças. Neste lado da fronteira há inúmeros fatores linguísticos motivados pelas relações comerciais, trabalhistas, religiosas, políticas, educacionais e culturais entre brasileiros e estrangeiros, inclusive bolivianos. Além disso, algumas atividades desenvolvidas em conjunto, principalmente na área de saúde, educação, meio ambiente e turismo ajudam a fortalecer ainda mais as relações linguísticas.

Comecemos, no entanto, primeiramente, pensando nos mais de 700 alunos bolivianos ou filhos de bolivianos, atualmente, matriculados nas escolas municipais de Corumbá-MS. Sabemos que a prefeitura municipal tem investido na formação e capacitação de professores para que trabalhem em Língua Espanhola, visando a atender a esses alunos e seu universo linguístico. Todavia, vale destacar que desde 1993, segundo Silva \& Rivas (2010), após a publicação do decreto lei municipal $n^{\circ}$ 1.322/93 que dispõe sobre implantação do ensino do espanhol nas escolas da Rede Municipal de Ensino (REME), tenta-se ofertar o ensino dessa língua nas escolas dos municípios de Corumbá. Entretanto, essa lei não saiu do papel. Conforme afirmam as autoras:

\footnotetext{
De acordo com dados fornecidos pelas escolas da Rede Municipal de Ensino, a oferta de língua estrangeira é feita no ato da matrícula dos alunos que irão iniciar o sexto ano do Ensino Fundamental. Nesse contexto a escola apresenta aos pais ou responsáveis uma ficha de oferta de língua estrangeira emitida pela Secretaria de Educação para preenchimento obrigatório. Os responsáveis pela matrícula do aluno sempre optam pela matrícula na língua inglesa, não demonstrando qualquer interesse pelo espanhol. (SILVA \& RIVAS, 2010.p.11).
}

Até 2012, segundo dados da Secretaria de Educação do Município, apenas algumas escolas de ensino fundamental ofereciam o ensino de língua espanhola de modo facultativo e outras do ensino médio disponibilizavam o ensino desse idioma, também de matrícula facultativa aos alunos. 
Sabemos, no entanto, que na região focalizada, as duas línguas nacionais estão presentes no dia a dia dos fronteiriços, seja em relações de informalidades, práticas individuais e coletivas, em serviços informais, de babás, garçons, etc., em serviços prestados em atendimentos realizados no sistema público de saúde, nas relações comerciais estabelecidas em espaço público, nas portas dos hotéis, no Porto Geral ou na área central de Corumbá, ou mesmo em relação aos festejos religiosos, tradicionais bolivianos comemorados em terras brasileiras, em que a missa é celebrada em espanhol (FERREIRA E SILVA, 2012).

No entanto, salientamos que, segundo Costa(2013):

A presença dos bolivianos em Corumbá é vista como um "problema social", sobretudo por parte da elite local, mas com um preconceito difuso por outros setores da sociedade, e existe, no discurso e na prática, a reprodução de preconceitos e de uma estigmatização em relação aos bolivianos e seus descendentes (COSTA, 2013).

Mas, apesar das inúmeras interações linguísticas presentes, ainda não se pode falar em região bilíngue, pois os moradores não são fluentes nos dois idiomas: falam apenas português ou espanhol. Ferreira e Silva (2012), alertam para o fato de que não se pode afirmar a existência de uma interlíngua, ou do "portunhol" nesta fronteira com a Bolívia, pois a linguagem não foi sistematizada - os estudos de influência do português no espanhol e do espanhol no português, no âmbito da fonética, do léxico, da sintaxe e da semântica, ainda estão no início. Segundo elas, o que se observa é que a influência do português sobre o espanhol é maior e pode ser explicada por fatores de ordem social de acordo com a sociolinguística laboviana.

Assim, afirmar que nesta fronteira fala-se portunhol é ainda considerado um equívoco, pois não há situação real e nem estudos que comprovam isso. O que se nota é que a designação mais frequente para o emprego da expressão "portunhol" está associada à ideia de se falar a língua espanhola de maneira imprecisa, segundo SILVA \& RIVAS (2010).

Destacamos que no lado brasileiro desta fronteira há grande interesse nos bolivianos em aprender a língua portuguesa e forte desinteresse nos brasileiros em aprender o espanhol. Neste contexto, reconhecemos que a língua também pode ser vista 
como uma poderosa força social que além de informar, permite que os sujeitos possam agir e reagir a ela e às suas características pessoais e sociais (CARGILE $\mathrm{E}$ GILES,1997). Assim, um fronteiriço brasileiro pode achar um indivíduo menos "culto" ou "refinado" simplesmente por possuir características físicas ou sotaque diferente do seu. Isso ocorre principalmente porque as crenças linguísticas podem influenciar na interação social e em contextos sociais.

Nesta perspectiva, Lambert (1967) direciona as análises para a manifestação de preferências e convenções sociais acerca do status e prestígio de seus, observando que os grupos sociais de mais prestígio, ditam a pauta das atitudes linguísticas nas comunidades de fala. Assim, a atitude linguística assumida pelo falante fronteiriço implica a noção de identidade, que se pode definir como a característica que permite diferenciar um grupo de outro, uma etnia de outra, uma nacionalidade de outra, enfim um e outro.

Desta forma, verificamos que as crenças e atitudes linguísticas nesta região representam e são representadas em importantes fenômenos comunicativos que, certamente, merecem ser explorados, pois representam um componente fundamental da identidade linguística do falante fronteiriço e possibilitam a compreensão do próprio comportamento linguístico da região. Além disso, estão relacionadas às reações positivas ou negativas que os falantes fronteiriços manifestam em relação à língua do outro.

Entretanto, se observarmos empiricamente a realidade desta fronteira, notaremos que existe uma complexidade que vai muito além da divisão dicotômica entre brasileiros e bolivianos. Para compreender isso é só recordar o processo histórico de construção desse espaço fronteiriço. Sabemos que, no início do século XX, os rios Paraguai, Paraná e Prata eram os únicos meios de comunicação da região. Desta maneira, a cidade brasileira vivia sob a influência dos países da Bacia do Prata, e assim herdou grande parte dos seus costumes, hábitos e linguagem. Após a Guerra do Paraguai, Corumbá-MS, margem esquerda do rio Paraguai, tornou-se um importante centro atrativo de inúmeros estrangeiros. 
A partir de 1912, para a região vieram imigrantes de diversas regiões e nacionalidades. As migrações de Minas Gerais, Rio Grande do Sul, Paraná e São Paulo e, principalmente, turcos, sírios, libaneses, palestinos, armênios, japoneses, alemães, italianos, portugueses, argentinos, espanhóis, franceses, uruguaios, paraguaios, entre outros. A partir de 1890, o estado, notadamente, apresentou uma população de estrangeiros crescente, superior a $6 \%$ da população total, até 1920. Depois o número decaiu, chegando, em 1970, a 3\% da população. Entre 1920 e 1970, em Corumbá, houve um tempo em que era difícil localizar quem falasse o idioma português, considerando que mais de $50 \%$ dos estrangeiros que habitavam o Mato Grosso eram paraguaios e outros 13\% eram naturais da Bolívia (REVISTA ATUAÇÃO, 2013).

Lembramos que, como ressaltamos no início deste capítulo, não é pretensão, neste trabalho, pormenorizar as atitudes linguísticas de cada migrante e imigrante encontrado na região. Esta é outra pesquisa que teremos a satisfação de expor posteriormente, em outro trabalho, mas cabe, aqui, abordar alguns detalhes importantes que merecem atenção e servem de sustento às reflexões. Assim, destacamos a existência de uma relativa porcentagem de paraguaios que se estabeleceram na região, devido a incorporação da mão-de-obra nas fazendas pantaneiras, depois da Guerra do Paraguai, como afirma Câmara (2007).

A influência paraguaia também foi de grande importância para a construção desta região fronteiriça, com hábitos oriundos da cultura guarani, esses imigrantes contribuíram com sua influência na apreciação da dança, músicas típicas, como a polca paraguaia, rasqueado, chamamé; pela culinária, como o gosto pela tradicional chipa e sopa paraguaia; ou pelo costume do consumo de erva-mate, em forma de tereré. Além disso, os paraguaios deram forte contribuição à forma de pronunciar as palavras, como salienta Câmara (2007). No linguajar pantaneiro, há também forte presença de muitas palavras paraguaias ou platinas, ou seja, de origem guarani. Câmara (2007) destaca que, dos paraguaios e bolivianos, o pantaneiro recebeu um acento castelhano em seu português estilizado, trazido pelos caipiras paulistas. CÂMARA (2007, p. 61). Enfim, ressalta-se que há na região uma situação singular que faz parte deste espaço fronteiriço, que participam migrantes e, principalmente, os imigrantes que desenvolvem a segunda 
língua em um contexto especial em que a língua portuguesa é utilizada como veículo de comunicação local (FERREIRA e SILVA, 2012).

Como as atitudes linguísticas são também atitudes psicossociais, ou seja, as línguas possuem conotações sociais, avaliadas a partir do status dos seus usuários, apesar da incorporação há algumas atribuições pejorativas, preconceituosamente incorporadas parte como herança da época da guerra, parte devido a muitos terem chegado ao pantanal devido a grande habilidade em lidar com o couro e a madeira, sendo eles grandes aceiros e realizadores de cercas, currais e outras construções pantaneiras.

Há ainda contribuições em relação à imigração dos árabes, o comércio foi a principal atividade econômica desenvolvida. Muitos iniciando como mascates, depois passando a varejistas e atacadistas. Essas atividades estenderam-se aos moradores ribeirinhos, aos moradores das fazendas de gado e por toda a região pantaneira próxima a Corumbá, fato que, consequentemente, alimenta fortes interferências culturais, linguísticas e espaciais. Mas, precisa-se esclarecer que antigamente qualquer imigrante oriundo de qualquer país árabe era chamado de turco, fosse egípcio, argelino, persa, palestino, sírio etc.

No entanto, convém salientar que a migração árabe merece, neste cenário, um destaque especial, considerando que estes iniciaram como mascates-fluviais, no início do século XX e, quando já tinham a possibilidade de abrir casa comercial, passaram a se instalaram na cidade. Assim fizeram várias famílias, como é o caso das famílias Haddad, Neder, Azar, Bacha, Chain, Safadi e Jebara, que depois de estabelecidos formaram uma comunidade, em sete de março de 1909 fundaram uma agremiação chamada "Sociedade de Beneficência Ottomana" (AYALA E SIMON, 1914, p. 337).

Muitos imigrantes ascenderam ao ramo financeiro, como é o caso do sírio Alfredo Zamlutti, que montou a primeira casa bancária da região em 1938. Outros se tornaram atacadistas como o sírio Salin Kassar, o argentino de ascendência síria João Dolabani e o sírio Alfredo Katurchi, que fundaram o "Moinho Mato-grossense (1952), a Fiação Mato-grossense e a Tecelagem Mato-grossense (1959) e, ainda um curtume (1960)" (OLIVEIRA, 2001, p. 35-36). 


\begin{tabular}{|c|c|}
\hline $\begin{array}{l}\text { Web Revista } \\
\text { 0. CLIALET0 }\end{array}$ & 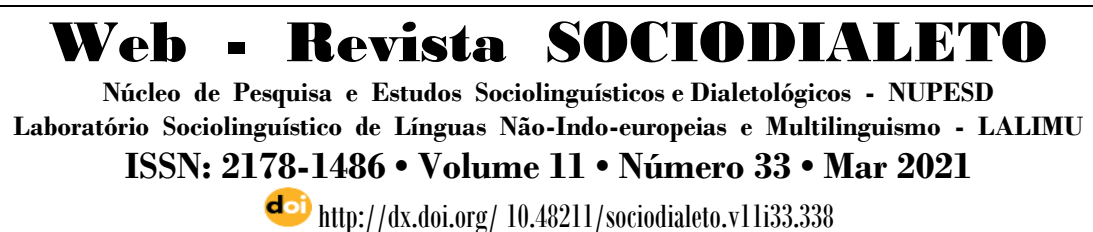 \\
\hline
\end{tabular}

Note:

Figura 2. Edifício Salim Kassar, testemunho da migração sírio-libanesa que começou no final do século XIX e teve importante papel no desenvolvimento comercial da cidade.

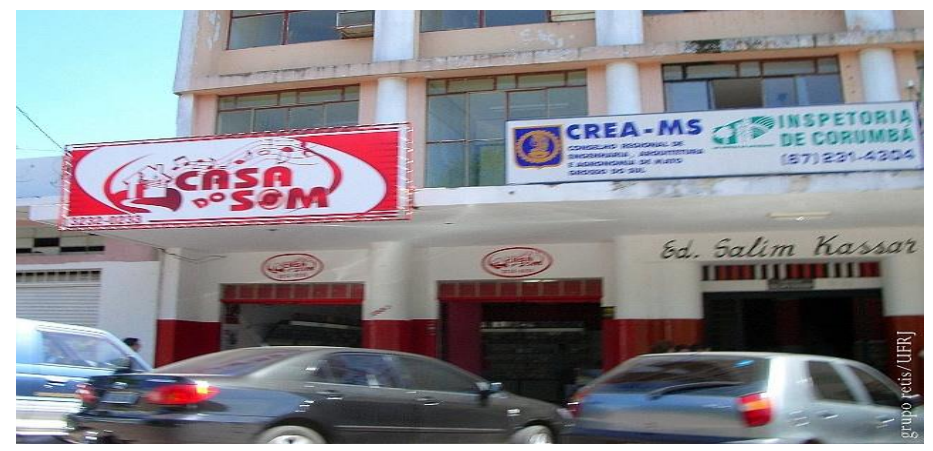

Foto: Licio Monteiro, 2006

Outros exemplos podem ser encontrados em frente ao Porto de Corumbá, local por onde chegou a riqueza, o progresso, o desenvolvimento, a cultura e o migrante. As casas comerciais aqui construídas, quando a cidade era importante centro atacadista no comércio fluvial do rio Paraguai, nas primeiras décadas do século $\mathrm{XX}$, são fortes exemplos da forte influência imigrante.

Figura 3. Casario do Porto em Corumbá-MS

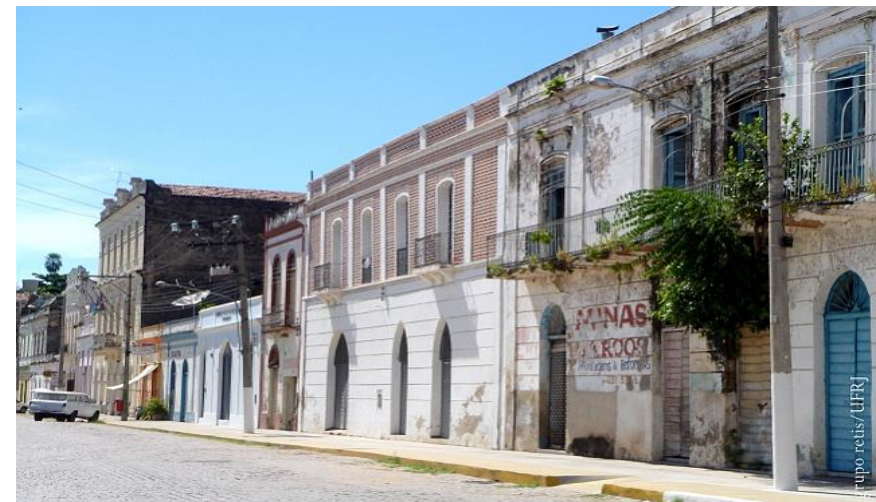

Foto: Licio Monteiro, 2006

A casa restaurada no centro da foto acima pertenceu à firma Stöfen, Schanack, Müller, fundada em 1898 e foi criada para importação, exportação, consignações e despachos na alfândega. A firma também exportava borracha de seringais próprios e 
tinha uma matriz em Puerto Suárez e filiais em Aquidauana, Rio Guaporé, rio Itenez e San Ignácio na Bolívia. Foi tombada pelo IPHAN. (MARQUES, 2001).

Além disso, estes imigrantes criaram nesta fronteira, no lado brasileiro, não apenas uma relação e identidade econômica e poder político, mas também forte influência linguística, religiosa e cultural, o que ajudou a manter a unidade e disparidade das populações árabes na sociedade corumbaense e pantaneira.

Lambert e Lambert (1975, p. 100) definem a atitude linguística como "uma maneira organizada e coerente de pensar, sentir e reagir em relação a pessoas, grupos, problemas sociais ou, de modo mais geral, a qualquer acontecimento no ambiente". Neste sentido, observamos que os imigrantes deixaram na região uma forte influência que, de certa forma, é fluxo natural dos contatos linguísticos e interculturais.

Exemplo disso encontra-se nas comemorações do dia 30 de março, o chamado “dia da Terra” em que marca a lembrança histórica da resistência de 1976, quando os palestinos da Galileia, território ocupado em 1948, manifestaram-se contra a invasão e ocupação de suas terras pelo Estado em Israel. Neste dia, palestinos, residentes em Corumbá, estendem a bandeira da sua pátria em frente à suas residências ou comércios realizando uma demonstração de amor ao seu país, conforme informou o vicepresidente do Centro de Cultura Árabe Palestino de Mato Grosso do Sul, Omar Fares ao jornal Diário (CAVALCANTE, 2011). Por outro lado, a língua usada majoritariamente neste tipo de encontro é a língua portuguesa.

Outro excelente exemplo pôde ser visto no ato pacífico realizado em 29 de julho de 2014, em homenagem às vítimas do conflito na Faixa de Gaza, em que alguns comerciantes palestinos e árabes fecharam as portas dos estabelecimentos e foram à Praça da Independência, no centro da cidade, e juntando-se a crianças e jovens descendentes e brasileiros, com os rostos pintados, estenderam cartazes em língua portuguesa e bandeiras da Palestina, pedindo paz para o Oriente Médio. Detalhe é que tanto os descendentes, jovens e crianças, como imigrantes palestinos, entrevistados por TV local, empregaram a língua portuguesa na comunicação. Inclusive o breve discurso proferido pelo Sr. Munther Safa, presidente da Sociedade Árabe-Palestina de Corumbá, também 


\begin{tabular}{|c|c|}
\hline $\begin{array}{r}\text { Web Revista } \\
\text { ODIALETO }\end{array}$ & 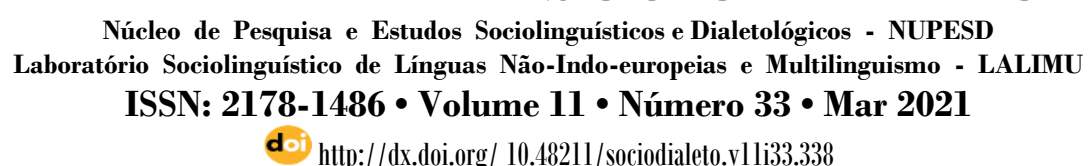 \\
\hline
\end{tabular}

ocorreu em língua portuguesa, afirmando ser "um massacre sem limites contra o povo palestino".

Figura 4. Cartazes escritos em Língua

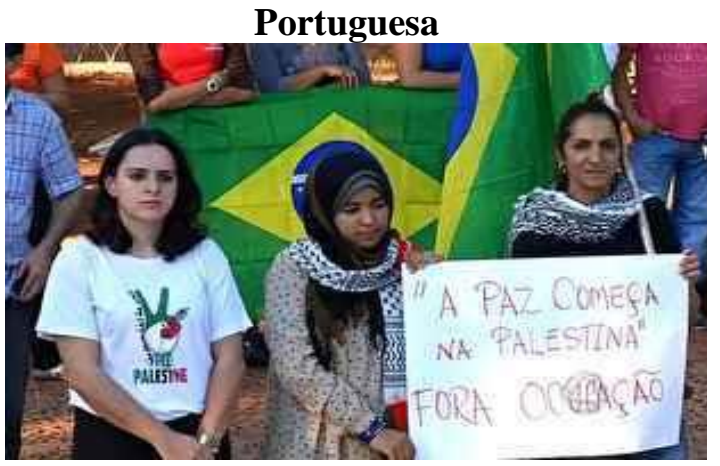

Figura 5. Discurso proferido em Língua Portuguesa

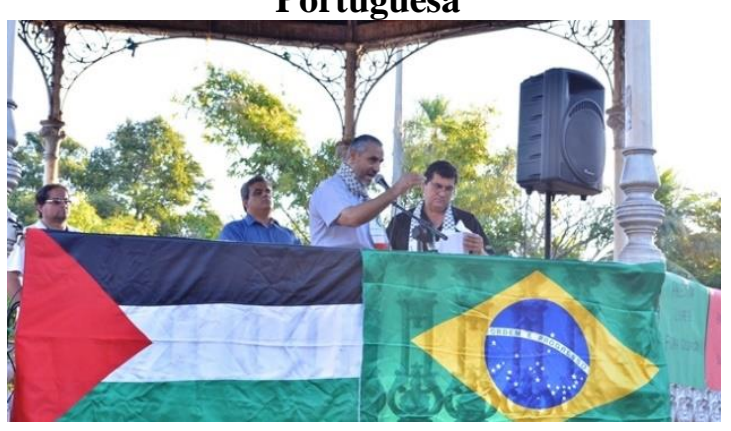

\section{Fonte: FETEMS}

Sabemos que, atualmente, a comunidade árabe-palestina de Corumbá reúne mais de 300 pessoas e é a maior de Mato Grosso do Sul. É notório que essa comunidade étnica (sírios, libaneses e palestinos), é importante historicamente na região não apenas pelas atividades comerciais que desenvolvem, mas também pela influência política da cidade e pela forte influência cultural expressa nos costumes da região. Um bom exemplo é o crescimento do número de usuários do cachimbo oriental, o narguilé, (jovens, homens e mulheres) no lado da fronteira brasileira. O Narguilé é um costume árabe com grande preponderância nos hábitos egípcios. O proposto do Narguilé é o tabaco fumado através de água quente com diferentes aromas naturais, desde a maçã (mais fraco) ao mel (mais forte). No entanto, essa febre juvenil, introduzida pelo contato com a cultura árabe em Corumbá, tem sido incorporada com outros costumes locais. Os adolescentes utilizam o narguilé junto ao tereré nos finais de tarde. Grande mostra da mistura cultural trazida pelos imigrantes. 


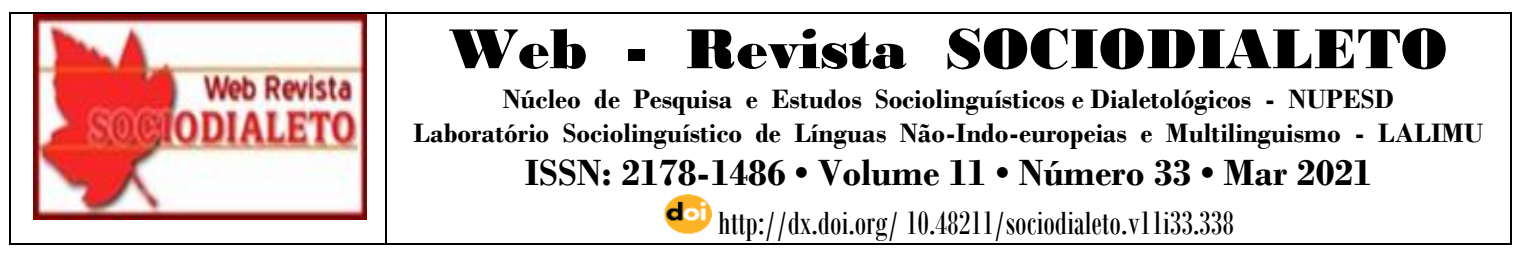

Figura 6. Fronteiriço fumando Narguilé uma tradição árabe, mas com variações regionais sobre a sua preparação e formas de consumo.

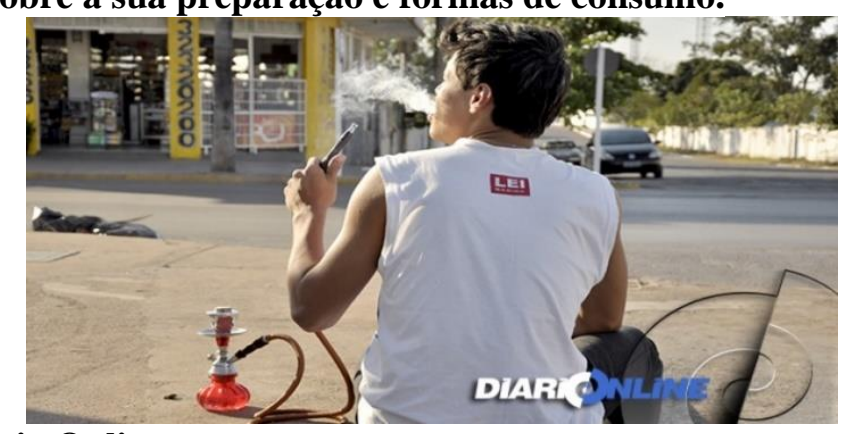

\section{Fonte: Diário Online}

A participação de árabes nos espaços da fronteira do Brasil, tanto dos próprios imigrantes como seus descendentes, faz-se presente nos mais variados campos sociais tornando sua língua e cultura elementos constitutivos da identidade da própria fronteira. Vejamos a exemplo o nome estabelecido para o clube-sede de eventos culturais, estabelecido para preservar as tradições, costumes e cultura, a Liga Árabe Brasileira de Corumbá, fundada em 1948.

Figura 7. Vista frontal da Liga Árabe Brasileira de Corumbá

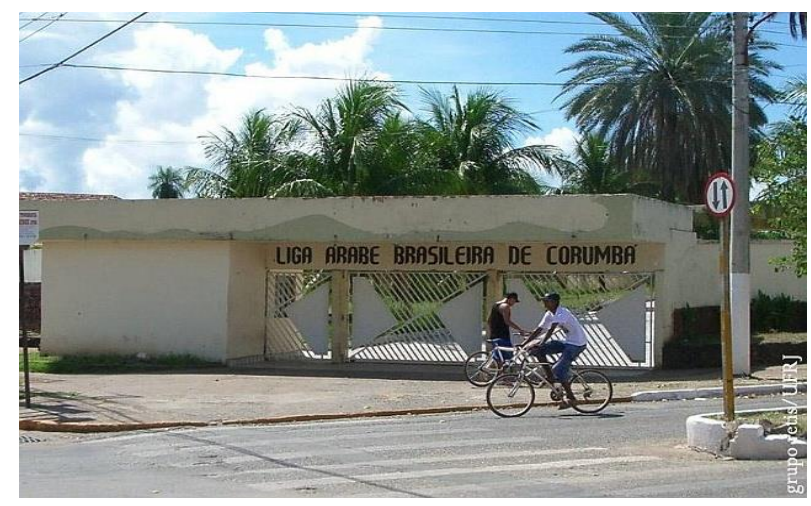

Fonte: retis.igeo.ufrj.br/album_iconografico

Salientamos ainda que, em relação á língua falada por esses imigrantes, também merece reflexão, pois ao chegarem ao Brasil, esses imigrantes falavam a língua árabe coloquial, não em sua versão gramatical clássica e rigorosa, pois segundo Goulart (1967), tratava-se de uma articulação linguística proveniente de pouco estudo. Além 
disso, a atividade de mascates colaborou com a rapidez e perfeição que adquiriram o idioma do país. (GOULART, 1967. grifo nosso).

No entanto, salientamos ainda que muito do que se fala hoje na região, também foi aprendido com esses imigrantes e vinculado às misturas, ou seja sofreram variações ao longo do tempo. Há influências linguísticas no vocabulário no Brasil, que não possui rigor científico, mas é importante para a lexicografia do português local. É o caso do vocábulo Alá ou Allah (em árabe transl. Allāh, AFI: [?al؟:a:h]), nome que designa "Deus". Sofrendo um grande distanciamento semântico esse vocábulo, na região, hoje, escreve-se com inicial minúscula e é empregado em sentido geral ou indeterminado, deixando de ter sentido de Deus ou Jeová, recebendo outra conotação, exprimindo espanto, admiração e surpresa. Trata-se de interjeição que enaltece o que foi ouvido. Este tipo de arabismo do português está distribuído em diversos campos semânticos. No entanto, convém ressaltar que também há na região a expressão “A la pucha” (a la putcha), do espanhol, que se trata de interjeição de surpresa que enaltece o que foi ouvido (âigate), que pode também ter influenciado a construção semântica do verbete.

Além das muitas trocas culturais e linguísticas presente na região, sabemos que a grande presença das forças armadas, das mineradoras e do turismo trazem para a fronteira brasileira práticas, hábitos e estilos de vida diferenciados, oriundos de várias regiões do Brasil. No entanto, merece destaque também o grande contingente de soldados e oficiais cariocas e fluminenses oriundos do Rio de Janeiro, através da Marinha, considerando a enorme interação social, cultural e linguística, mas sobre isso, abordaremos em outra ocasião.

Por outro lado, no lado brasileiro, apesar de existir essa grande variação social, cultural e linguística, é possível encontrarmos também, em proporção menor, certa complexidade cultural e linguística, no sentido de possuir registro de resistência por parte dos moradores mais idosos que buscam manter muitas características antigas e, provavelmente, típicas da região, ainda preservadas depois de muitas gerações. A manutenção linguística por parte dos mais velhos caracteriza o desejo de manter vivas as tradições locais como aponta Silva (2004).

Relata ainda Silva(2004) que: 


\begin{abstract}
O que ocorre em Corumbá e Ladário é semelhante ao episódio de Marthas de Vineyard: a palatalização do Isl pós-vocálico predominante na fala das comunidades se configura como marca cultural local e se contrapõe à pronúncia dos migrantes, identificando-os e discriminando-os, na maioria das vezes (SILVA, 2004, p. 40).
\end{abstract}

Após todas essas colocações, destacamos que nos preocupamos, sobremodo, com o estudo da língua em uso no seio das comunidades de fala. Assim, optamos por focalizar os princípios teóricos da sociolinguística variacionista, que se interessa em abordar questões estruturais da linguagem, suas formas e organização subjacentes, além de conhecer o mecanismo e as causas da própria mudança linguística, conforme afirma Labov (2007, p. 2). Assim, verificamos, nessas reflexões, como a variação e a mudança linguística encaixaram-se no contexto social desta comunidade fronteiriça e encontramos inúmeras especificidades nesta língua, empregada na comunicação com os "outros" na vida cotidiana. Finalmente, afirmamos que as atitudes linguísticas oriundas desse contexto pode estar diretamente relacionadas às relações de poder e lutas ideológicas, que emergem nos discursos e, que reconstroem identidades em face de processos sociais, muitas vezes conflituosos. Nesse cenário, afirmamos que a aprendizagem de uma segunda língua nesta fronteira pode significar a emergência de uma nova identidade, um novo "eu" em que a língua é o principal veículo dessa emergência.

Destacamos também que devido à proximidade das cidades, entre outros motivos, muitos bolivianos de localidades como: Puerto Suarez, Cochabamba, La Paz, Roboré, Potosí, São José de Chiquitos, São Miguel, San Ignacio de Velasco, Trinidad, dentre outras, também resolveram ingressar no Brasil (FERREIRA E SILVA, 2012. p. 02-03). Além disso, no final dos anos 70, o turismo começou a ser explorado, instala-se na cidade a Urucum Mineração e a Companhia Vale do Rio Doce e nos anos 80, finalmente, consolida-se o turismo. Tudo isso mudou a economia de Corumbá e consequentemente, houve um acréscimo na demanda turística local, com a inauguração de vários restaurantes, bares, hotéis, pousadas, barcos-hotéis, entre outros. Em 1986, militares, a rodovia que liga Corumbá à capital foi pavimentada pelos o que dinamizou 
o comércio local. Hoje, é caracterizada como um dos principais polos turísticos no Estado de Mato Grosso do Sul e conhecida como capital do Pantanal.

Assim, estudar a língua como objeto de construção social, considerando sua singularidade, ajuda-nos a compreender as variações sociais, regionais, geográficas e o discurso enquanto a própria expressão linguística e social do ato da comunicação nesta fronteira. Relembramos que, inicialmente, afirmamos que o estudo sobre atitudes e crenças linguísticas em região fronteiriça ainda está em fase embrionária, mas conforme afirma Tarallo (1985, p.14), as atitudes linguísticas são armas usadas pelos residentes para demarcar seu espaço, sua identidade cultural, seu perfil de comunidade, de grupo social separado. Assim, além da importância social, as atitudes linguísticas nesta região influenciam os processos de variação e mudança linguística e nessa perspectiva, as atitudes atuam regularmente nos modos de reagir dos sujeitos fronteiriços, modificando segundo as novas experiências, contudo, com o passar do tempo, tornam-se inflexíveis e estereotipadas. Lambert e Lambert (1975, p.101) afirmam que os indivíduos podem ser estimulados, por longos períodos, a reagir de modo padronizado a determinados acontecimentos ou a determinados grupos.

Enfim, afirmamos que as atitudes linguísticas, evidentemente, associadas às crenças não são estáticas nesta fronteira, pois dependem da complexidade das relações sociais aqui presentes e podem ser alteradas com o tempo, considerando que são socialmente construídas nas relações de interação e contato entre os grupos existentes nesta zona de fronteira.

\section{REFERÊNCIAS}

AJALA, Erisvaldo Batista. O PCdoB e a gestão avançada de Paulo Duarte (PT) em Corumbá-MS. Portal Vermelho, São Paulo, 12 abr. 2014. Disponível em: http://www.vermelho.org.br/noticia/240033-79. Acesso em: 05 jan. 2015.

BOLÍVIA: Censo Nacional de Población y Vivienda 2001. 10 vol. INE. La Paz, Bolivia.

CALVET, L. Sociolinguística: uma introdução crítica. Trad. de Marcos Marcionilo. São Paulo: Parábola, 2002.

BAKHTIN, M. Marxismo e filosofia da linguagem. São Paulo: Hucitec, 1988. 
CÂMARA, Marcelo A. Os Movimentos Sociais de Base Indígena e a Construção de Identidade Sócioterritorial na Bolívia. ESPAÇO E CULTURA, UERJ, RJ, №. 19-20, P. 71-78, JAN./DEZ. DE 2005.

CÂMARA, Marcelo A. O Movimento Campesino e A Re-Significação da Identidade na Bolívia. Anais do X Encontro de Geógrafos da América Latina - Universidade de São Paulo, 20 a 26 de março de 2005B.

CÂMARA, Ricardo Pieretti. Os causos: uma poética pantaneira. 2007. Tese (Doutorado em Humanidades) - Faculdade de Filosofia e Letras, Universidade Autônoma de Barcelona, Barcelona, 2007.

CARGILE, Aaron C. et al. Language attitudes as a social process: a conceptual model and new directions. Great Brintain, Elsevier Science Ltd. Language \& Comumunication, vol. 14, $\mathrm{n}^{\circ}$. 3, p. 211-236, 1994.

CARGILE, Aaron C.; GILES, Howard. Understanding language attitudes: exploring listener affect and identity. Great Brintain, Elsevier Science Ltd. Language \& Comumunication, vol. 17, $\mathrm{n}^{\circ}$. 3, p. 195-217, 1997.

CAVALCANTE, Camila. Em Corumbá, palestinos comemoram "Dia da Terra ". Diário Online. 30 de Março de 2011. Disponível em http://diarionline.com.br/index.php?s=noticia\&id=28193. Acesso em 14 jan 2015.

CAVALCANTE, Camila. Narguilé é tão nocivo quanto o cigarro, alerta Saúde. Disponível em: http://www.diarionline.com.br/index.php?s=noticia\&id=48821 . Acesso em 12 jan 2015.

COSTA, Gustavo Villela Lima da. O muro invisível: A nacionalidade como discurso reificado na fronteira Brasil-Bolívia. p 144, Tempo Social, revista de sociologia da USP, v. 25, n.2.Novembro, 2013.

CERRÓN-PALOMINO, R. Linguística Quechua, Centro de estudios rurales andinos «Bartolomé de las Casas», Cuzco. Disponivel em http://www.gentedeopiniao.com.br/lerConteudo.php?news=36441. Acesso em 07 jan 2015 .

EAGLETON, T. A ideia de cultura. São Paulo: Ed. Unesp, 2005.

FERREIRA, Stael Moura da Paixão. SILVA, Rosangela Villa da. Algumas Reflexões Sobre Os Contatos Linguísticos na Fronteira Brasil-Bolívia: As Hibridações Étnicas, Culturais e Sociais. In: Revista Internacional ESTUDIOS HISTORICOS. n. 09, Año IV. Diciembre 2012. Uruguay. Disponível em: www.estudioshistoricos.org/edicion9/eh0905.pdf. Acesso em 17 jan 2015

GÓMEZ MOLINA, J. R. Actitudes lingüísticas en una comunidad bilíngüe y multidialectal: area metropolitana de Valencia. Anejo n.o XXVIII de la Revista Cuadernos de Filología. Valencia, Universitat de Valencia, 1998.

GOULART, José Alipio. O Mascate no Brasil. Conquista, 1967. 
LABOV, William. Sociolinguistc patterns. Philadelphia: University of Pennsylvania Press, 1972.

LABOV, William. Padrões sociolinguísticos. (Tradução Marcos Bagno, Marta Maria Pereira Scherre e Caroline Cardoso) São Paulo: Parábola Editorial, 2008 [1976].

LABOV, William. Sociolinguística: uma entrevista com William Labov. Revista Virtual de Estudos da Linguagem - REVEL. Vol. 5, n. 9, agosto de 2007. Entrevista concedida a REVEL. Tradução de Gabriel de Ávila Othelo. ISSN 1678-8931 (www.revel.inf.br). Disponível em: <http://www.revel.inf.br/files/entrevistas/revel_9_entrevista_labov.pdf> Acesso em:04 out de 2014.

LAMBERT, Wallace. E. A social psychology of bilingualism. Journal of social Issues, 23, 91- 109, 1967.

LAMBERT, William W.; LAMBERT, Wallace E. Psicologia social. 4 ed. revista e ampliada. Trad. Dante Moreira Leitel. Rio de Janeiro: Zahar, 1975.

LAMBERT, W. HODGSON, R., GARDNER, R. and FILLENBAUM, S. Evaluational reactions to spoken languages. Journal of Abnormal and Social Psychology 60, 4451. 1960 .

MANGOLIM, Olívio. Povos indígenas no Mato Grosso do Sul: viveremos por mais 500 anos. Campo Grande, MS: Conselho Indigenista Missionário Regional de Mato Grosso do Sul, 1993.

MARRA, Daniel \& MILANI, Sebastião Elias. Reflexões acerca do conceito de língua como uma instituição social em William Dwight Whitney. Universidade Federal do Rio Grande do Sul. Cadernos do Instituto de Letras, Porto Alegre, n. ${ }^{\circ}$ 46, junho de 2013. p. 129-147. Disponível em: https://seer.ufrgs.br/cadernosdoil/article/view/35837/25719. Acesso em out. 2020

MARQUES, Rubens da Costa. Trilogia do Patrimônio Histórico e Cultural SulMato-Grossense, 2001.

OLIVEIRA, Marco A. M. de. O Mais Importante era a Raça. Sírios e Libaneses na Política em Campo Grande, MS. Tese de doutorado. F.F.L.C.H., USP, 2001.

ORGANIZAÇÃO DAS NAÇÕES UNIDAS. Cepal. Los pueblos indígenas de Bolívia: diagnóstico sóciodemográfico a partir del censo de 2001. Santiago: ONU, 2005.

OTA, Daniela. LINHARES, Gladis. Jornalismo local nas fronteiras do Brasil, Paraguai e Bolívia. Trabalho apresentado no I Colóquio Transfronteiras Sul de Ciências da Comunicação: Brasil, Argentina, Paraguai e Uruguai. Evento componente do XXVII Congresso Brasileiro de Ciências da Comunicação, Porto Alegre, RS, 2004.

POSTIGO, A. V. Apontamentos fonológicos sobre as listas de palavras guató (MacroJê). 2011. Estudos Linguísticos, São Paulo, 40 (1): p. 275-289, jan-abr de 2011.

REVISTA ATUAÇÃO. Pouca idade, mas muita história - Mato Grosso do Sul, 36 anos. p. 40. FETEMS: Campo Grande - MS. Novembro 2013. 
REPORTAGEM: http://globotv.globo.com/tv-morena/bom-dia-ms/v/comunidadepalestina-realiza-ato-em-homenagem-as-vitimas-do-conflito-na-faixa-de-gaza/3530666/

REVISTA FETEMS. Fetems participa de ato público em solidariedade às vítimas da ofensiva de Israel em Corumbá. Fetems. 02/08/2014 09h33. Disponível em : http://www.amambainoticias.com.br/cidades/fetems-participa-de-ato-em-solidariedadeas-vitimas-de-israel-em-corumba. Acesso em 14 jan 2015

REVISTA MATO GROSSO DO SUL SEM FRONTEIRAS: Características e interações territoriais Bolívia- Brasil- Paraguai. / [organização SEBRAE/MS].1.ed. Campo Grande, MS: Visão: SEBRAE/MS, 2010. Disponível em: http://semfronteiras.ms.sebrae.com.br/uploads/download/LIVROfinal.pdf. Acesso em: 04 jan 2015.

REVISTA TEKOHA. Publicação especial do Dia do Índio do MPF/MS. $3^{a}$ edição Abril de 2012. Disponível em http://www.prms.mpf.mp.br/servicos/sala-deimprensa/publicacoes/tekoha-3-dia-do-indio-2012-mpf-ms/Tekoha-III-MPFMS.pdf . Acesso em 05 jan 2015.

RIBEIRO, Hamilton. Documentário Índios Canoeiros do Pantanal. Disponível em: http://videolog.uol.com.br/video.php?id=249802. Acesso em 04 jan 2015.

SEIFFERT, Daniel Moura; ALMEIDA, Victor Gabriel Boson Silva. O reconhecimento do plurinacionalismo em uma constituição nacional. Trabalho apresentado ao V Congresso da ABraSD, Faculdade de Direito de Vitória (FDV), Vitória/ES, 2014.

SAUSSURE, F. Curso de Linguística Geral. São Paulo: Cultrix, 1995 [1916].

SILVA, Giani Ramona da. Educação Matemática entre jovens e adultos Guató: Relato de Experiência na Escola Estadual Indígena "JOÃO QUIRINO DE CARVALHO" TOGHOPANAÃ, CORUMBÁ, MS. Trabalho apresentado no IX Encontro Nacional de Educação Matemática - IX ENEM. 2007. Disponível em: www.sbembrasil.org.br/.../Relato_de_Experiencia/.../RE08610433838T.Acesso em: 05 jan 2015.

SILVA, Rosângela Villa da. Aspectos da pronúncia do $\langle\mathrm{s}>$ em Corumbá - MS: uma abordagem sociolinguística. Campo Grande (MS): Ed. UFMS; São Paulo: Arte \& Ciência, 2004.

TARALLO, Fernando. A pesquisa sociolinguística. São Paulo: Ática, 1985.

TCHOUGOUNNIKOV, S. O dialogismo e a paleontologia da linguagem: o Círculo de Bakhtin na episteme soviética. Conexão Letras. Revista do PPG-Letras da UFRS, n.1, 2005 .

WHITNEY, W. D. A vida da linguagem. São Paulo: Editora Vozes, 2010.

Recebido em: 30/10/2020 | Aprovado em: 06/01/2021. 